\title{
THE IMPACT OF CORRUPTION ON THE DEVELOPMENT OF LEGAL AND ECONOMIC SYSTEMS OF STATE
}

\author{
Oleksandr Sviderskyi ${ }^{1}$, Andrii Lubentsov ${ }^{2}$
}

\begin{abstract}
The purpose of the article is to examine the impact of corruption on the development of legal and economic systems of State. The subject of the research is the impact of corruption on the development of legal and economic systems of States. Methodology. Research methods are chosen based on the object, subject and purpose of the study. The study used general scientific and special methods of legal science. Thus, the analysis and synthesis method as well as the logical method were used to formulate a holistic view on corruption, its features, aspects as well as the ways in which it can be manifested. The logical-semantic method was used to establish the meaning of the term "corruption", "informal sector", "legal system". The comparative method was used when analyzing scientific categories, definitions and approaches. The legal modeling method has been applied to develop proposals for improving anti-corruption regulatory framework. Results. The article generalizes scientific views on the interpretation of the concept of corruption, on the basis of which the authors' view on this category is proposed. Psychological and sociological aspects of corruption are explored. The scientific opinion that corruption is a negative phenomenon that impedes the proper functioning of social, economic and legal systems of State is substantiated. Practical implication. Particular attention is paid to the fact that corruption is directly related to the informal sector. Therefore, it is emphasized that the legislator should create all the necessary organizational and legal conditions in order to minimize the risks of corruption in State. Value/originality. There is a need to raise legal awareness of citizens as an important factor in counteracting corruption and its manifestations in society, because nowadays corruption is treated with higher tolerance, is being taken for granted, that is, it is becoming a norm in modern society.
\end{abstract}

Key words: corruption, social sphere, economic system, legal system, legislation, counteraction.

JEL Classification: P49, Z19

\section{Introduction}

The phenomenon of corruption has a long history, as, according to historical sources, it arose at the same time as establishment and development of power and monetary relations in society. The first mention of corruption, as a negative form of civil service, is contained in the oldest historical monuments known to humankind: in the archive of ancient Babylon, dating from the second half of the 24th century B.C. E. In the Sumerian and Semitic era, King Lagash (an ancient citystate in Sumer on the territory of modern Iraq) reformed government to stop abuses of officials and judges, as well as to reduce illegal remuneration of temple staff by royal administration, to reduce and streamline the payments for rituals (Beliavskii et al., 1956). Over the centuries, corruption has been constantly evolving, changing, taking on new forms. This has led to the fact that today it affects the economies of virtually every country in the world. It should be noted that corruption, as a negative economic and legal phenomenon, not only obstructs the effective functioning of State and public processes in it, but it also poses a threat to the national security of the country, undermining it both internally and externally. However, the worst, in our opinion, is the fact that corruption is now being taken for granted, that is, it is becoming a norm in modern society and this cannot but be a cause of concern both for the legislature and for the representatives of the academic community.

\section{Presentation of the main material}

It must be noted that to date, the issue of corruption and the ways to counter it were considered by the experts from different countries. It was considered from a legal, economic, philosophical, social, political perspective. Besides, the issue of combating corruption has been repeatedly addressed in various international

\footnotetext{
Corresponding author:

${ }^{1}$ M.S. Bokarius Kharkiv Research Institute of Forensic Examinations, Ukraine.

E-mail: Sviderskyi_O@ukr.net

${ }^{2}$ M.S. Bokarius Kharkiv Research Institute of Forensic Examinations, Ukraine.

E-mail:AndriiVLub@gmail.com
} 
forums, conferences, etc. All this has led to the development of various concepts, programs, etc. at the intergovernmental level, aimed at counteracting this negative phenomenon. It should also be noted that legal scholars, justifying the feasibility of conducting research on the issue of combating corruption, pay attention to the versatility of this issue, as well as to the fact that it has a negative impact on all spheres of public life. However, notwithstanding the above, today there is still no consensus on the kind of impact that corruption has on the development of legal and economic systems of State. Therefore, the presented article will work on this issue.

When starting the scientific research, we should first find out, which is a corruption. In Roman law, the definition of "corrumpere" was interpreted as damaging, breaking, destroying, bribing and signifying unlawful acts in judicial practice, in particular, impeding the normal proceedings or the process of managing public affairs (Stashys, 2001). For the first time definition of corruption in its modern usage was given in 1425 , and was determined as the "deviation from righteousness and loyalty in the performance of duties" (Robertson, 2006). Today, the concept of corruption has been interpreted both in the reference literature and at the doctrinal level.

Thus, according to the explanatory dictionary of the modern Ukrainian language, "corruption" should be interpreted as: 1) the activity of persons authorized to perform the functions of the State, aimed at the unlawful use of their powers to obtain material goods, services and other benefits; 2) direct use by the official of his (her) position for personal enrichment; 3 ) venality of government officials and public figures (Busel, 2003). In the International Police Encyclopedia, corruption is defined as activities of persons, authorized to perform the functions of the State, aimed at unlawful use of their powers to obtain material goods, services, privileges or other benefits. Corruptive acts are: a) unlawful receipt of material goods, services, privileges or other advantages, in particular the acceptance or receipt of items (services) through the acquisition at a price (tariff), which is substantially lower than their actual (true) value by a person authorized to perform the functions of the State when performing such functions; b) obtaining by a person authorized to perform the functions of the State, credits or loans, purchase of securities, real estate or other property with the use of privileges or advantages, which are not provided by the legislation (Kovalenko et al., 2001).

In The Anti-Corruption Plain Language Guide (Transparency International, 2009) corruption is also interpreted as the abuse of entrusted power for private gain. Corruption can be classified as grand, petty and political, depending on the amounts of money lost and the sector where it occurs. Petty corruption is everyday abuse of entrusted power by public officials in their interactions with ordinary citizens, who often are trying to access basic goods or services in places like hospitals, schools, police departments and other agencies. Grand corruption is the abuse of high-level power that benefits the few at the expense of the many, and causes serious and widespread harm to individuals and society. It often goes unpunished. Political corruption is manipulation of policies, institutions and rules of procedure in the allocation of resources and financing by political decision makers, who abuse their position to sustain their power, status and wealth (Soloviov, 2011).

V.D. Hvozdetskyi (2012) notes that corruption is a complex and multidimensional social phenomenon (legal, economic, political, moral and psychological). The social essence of corruption is manifested in several ways: it is socially constructed (is a product of social life); has social cost that society pays for corruption, has a significant impact on the most important social processes; has historical origins and global character; it is legal, economic, political, psychological and moral phenomenon; it an ability to adapt to social realities, constantly reflecting and changing. The specific manifestations of this social phenomenon receive legal and moral appreciation from the State and society, reflecting the social essence of corruption. Corruption characterizes the main social processes occurring in State and society, in which the most significant problems for State and society are reflected.

V.I. Popov (1996) defines corruption as a set of various acts (acts or omissions) expressed in the unlawful receipt of property, services or privileges by a person authorized to perform public functions, in the unlawful provision of property, services or privileges, in the mediation or incitement to such actions from the interested person.

S.M. Klimova and T.V. Kovalova (2012) characterize corruption as a complex social phenomenon, which consists in the use of official position for personal gain, adversely affecting all aspects of political and socioeconomic life and development of society and State.

Thus, based on the views discussed above, it can be stated that corruption, as the activity, is the use of the powers by authorized entities to gain undue benefits (in the form of financial or material remuneration). In turn, defining the concept of corruption as a phenomenon, scientists agree that it primarily has a negative social aspect. Therefore, before determining the impact of corruption on legal and economic systems of State, it is necessary to determine its social as well as psychological aspects.

The psychological aspects of corruption take the following forms (types): misuse of power or office, abuse of power or office, other official crimes committed for selfish or other personal interests or to serve the interests of the others; theft of State, collective or private property using official position; unlawful receipt of material or other goods, benefits and other privileges; obtaining credits, loans, assistance, purchase of securities, real estate or other property using benefits or privileges, which are not provided by law or to which 
the person is not entitled; bribery; running business directly and through the intermediaries or subordinates using official powers, as well as related opportunities; assistance to natural and legal persons in running business using official position in order to obtain material and other benefits; undue interference in the activities of other State bodies or officials using official position in order to hinder the performance of their professional duties or to make them to issue unlawful judgments; the use of information obtained in the course of duty for selfish or other personal interests, unjustified refusal to provide relevant information or its untimely provision, or the provision of unreliable or incomplete official information; providing unjustified benefits to natural or legal persons through the preparation and adoption of regulatory acts or management decisions; protection of selfish or other personal interests in the appointment of the person who has no professional and business qualities that would give him (her) advantages over other candidates (Akimov, 2014).

As for the sociological aspect of corruption, M.I. Melnik (2002) notes that the social essence of corruption is manifested in several ways: it is socially constructed (is a product of social life); has social cost that society pays for corruption, has a significant impact on the most important social processes; has historical origins and global character; it is legal, economic, political, psychological and moral phenomenon; is an ability to adapt to social realities, constantly reflecting and changing. It is primarily manifested in the fact that it has social conditioning (is a product of social life), has a social price that society pays for corruption; significantly influences the most important social processes; has historical origins and global character; is an economic, political, legal, psychological and moral phenomenon; has the property of adapting to social realities, constantly changing. Therefore, it is certainly the fact that when investigating corruption it is necessary to pay attention to the social consequences of corruption manifestations, since it leads to a significant difference between declared and real values, which creates a "double standard" of morality and behavior at the public macro-level, and the phenomenon of "institutional duality" at the macrostructures level. It is through corruption that the civilized social regulators of human behavior (norms of morality, law, religion, public opinion) are devalued and destroyed; E. Durkheim called this process "value anomie". In general, it is a state of society, in which a significant part of its members, knowing about the existence of binding rules, treat them negatively or indifferently. Corruption discredits law as the main instrument for regulating life of State and society, as well as the State as the main public institution (Official web site of Solomianskyi district state administration, 2014).

Thus, corruption should be considered as one of the most negative phenomenon that has a devastating impact on society. It is because of this that the level of public confidence in public authorities in particular and in the State in general decreases. As a result, citizens are suspended from the problems of State and society, which in turn leads to the loss of a sense of social solidarity, justice, etc. We are convinced that it is precisely because of the existence of corruption in society that the value of the profession of a civil servant is declining, and honor, dignity and high status of persons who carry out their activities on behalf of the State are diminished. Therefore, it can be said that corruption "consumes" society of the center, hinders not only its social development, but also the formation of legal and economic systems of State.

Another area, which is adversely affected by corruption, is the economic one. The economic sphere is the environment, for which an official becomes involved in corruption relations, where corruption is powered and where profits are the greatest. Therefore, the reverse impact of corruption on the economy is especially dangerous, because it reduces the effectiveness of the economic policy of the State, forces the private business to move into informal sector, which entails breach of legislation, misrepresentation of tax system and the rules of business activity, forces the entrepreneurs to resolve their problems outside the legal framework (Dzhuzha, 2010). The most negative effects of corruption on the economy include:

- the expansion of informal sector. This leads to the reduction of the tax inflow to the budget;

- the violation of the competitive mechanisms of the market because often the winner is not the one, who is competitive, but the one, who is able to gain the benefits illegally. This leads to a decrease in market efficiency and a discrediting of competition ideas;

- the emergence of efficient private owners is slowing down, primarily due to privatization violations and artificial bankruptcies, usually connected with corruption of officials;

- the inefficient use of budget funds, in particular when allocating State procurement and benefits. This exacerbates the budgetary problems of the country;

- the increase of prices at the expense of "corruption costs". As a result, the consumer suffers;

- the lack of agents' confidence in the ability of the authorities to establish, control and adhere to fair market rules;

- the deterioration of the investment climate, resulting in failure to overcome the downturn and update fixed capital;

- the expansion of the scale of corruption in nongovernmental organizations (firms, enterprises, social organizations). This leads to a decrease in the efficiency of their work and, accordingly, the efficiency of the country's economy as a whole (Dzhuzha, 2010).

In our opinion, particular attention should be paid to the point that corruption is directly related to the informal sector. The informal sector is an economic 
activity, the entities of which avoid official accounting and tax payments. Three types of informal sector are usually identified by the nature of activity and the sources of income: 1) informal economy is the legalized (permitted) economic activities, the subjects of which avoid official accounting and justify their actions by the situational need for physical survival. It is the largest segment of the informal sector, represented by various types of small-scale production of goods and services (for example, music or photography services at weddings, associated transportation of passengers or cargo, tutoring, repair and construction works under the contract with individuals, selling products from household plots in "floating" markets) (Blank, 2016). The activity, which is caused by the latest technological advancements and is not subject to current legislation yet, which is too difficult to evaluate for taxation due to its virtual nature (for example, so-called home office, when it is possible to earn money without leaving home) is being added to the above activities; 2) hidden economy is legal economic activity, the subject of which are usually entrepreneurs, who fare involved in various organizational and financial manipulations for obtaining super-profits (for example, artificial fragmentation of big business for obtaining tax preferences for small business, using barter deals for profit, informal payments to employees to deceive the State (envelope salaries).This economy is also called the gray economy, as the expenses are still legal and the income is illegal; 3 ) the criminal economy is illegal (criminal) activities in the form of financial fraud, theft, smuggling, corruption, drug trafficking, pimping, racketeering, human trafficking and so on. Such an economy is called the black economy, because its income and expenses are illegal (Blank \& Batrakova, 2016).

Taking into account the above, the negative impact of corruption on the economy is not in doubt. We are convinced that there is a direct link between corruption and the state of the economy, as evidenced by relevant statistics. In particular, even a superficial analysis of the existing indicators makes it possible to note that it is obvious and undisputed that the higher the level of corruption in a country, the lower its economic development. Thus, corruption, combined with other social and political factors, significantly slows down the pace of economic development of the country, reduces financial activity of domestic and foreign investors, as well as ordinary citizens.

And the last aspect we will pay attention to is the impact of corruption on legal system of State. In general, the legal system can be considered from two perspectives: 1) in a broad sense as a set of interconnected uniform legal means (phenomenon), by which the authorities exert stabilizing, regulatory and managerial influence on social relations (by securing, specific or general regulation, authorization, obligation, prohibition, persuasion and enforcement, warning, imposition of sanctions, etc.); 2) in a narrow sense, the legal system is the unity of legal norms of national law and legislation, which consist of the central part (constitution), offshore (sectoral) and complex (intersectoral) laws (Kondratiev, 2004). In this context, the negative impact of corruption is quite broad and vast, and covers a wide range of relationships.

Particular attention should be paid to the fact that today corruption has a direct impact on the formation of legislation in States. After all, the subjects, which are empowered to make laws and to adopt them, are using their positions to form a system of legislation taking into account the wishes of private business, thereby creating all the necessary conditions for the development of the activity of particular business entity, hampering the work of the others. Therefore, it is corruption in legal system of State that creates a peculiar basis for the further "development" of this phenomenon and its penetration into all other spheres of public life.

\section{Conclusion}

Corruption is a very destructive phenomenon, which influences all spheres of public life. Concluding the presented scientific research, it is safe to state that corruption is a "disease" of modern society, which hinders its normal development. We noted that corruption has a negative impact on social, economic and legal systems of State, which is confirmed by masses of statistical data and scientific researches of the specialists. The most negative effects of corruption on the economy are:

1. Expanding the shadow economy.

2. The competitive mechanisms of the market are violated because often the winner is not the one, who is competitive, but the one, who is able to gain the benefits illegally.

3. The emergence of efficient private owners is slowing down, primarily due to privatization violations and artificial bankruptcies, usually connected with corruption of officials.

4. Budget funds are inefficiently used, in particular when allocating State procurement and benefits.

5. Prices are rising at the expense of "corruption costs".

6. Agents have a lack of confidence in the ability of the authorities to establish, control and adhere to fair market rules.

7. The investment climate is deteriorating, resulting in failure to overcome the downturn and update fixed capital.

8. The scale of corruption in non-governmental organizations (firms, enterprises, social organizations) is expanding.

Success in the fight against corruption depends, on a large extent, on how well and deeply its social essence is understood. Determining the social and legal nature of corruption, its essential features, formulating a scientific 
definition of the concept of "corruption", establishing relationships with other legal phenomena is fundamental both for the study of the legal nature of corruption and for practical activities in the area of combating corruption. It is also very important to adopt effective normative framework for regulating this issue. It is necessary to determine, which acts should be considered as corruption, which categories of offenses they belong to and what legal assessment they should receive.
Therefore, it is the responsibility of any modern democratic and socially-oriented State to create all the necessary organizational, legal and economic conditions to counteract corruption and any of its manifestation. However, in our opinion, it is not enough to pay attention only to the above mentioned aspects, it is important to raise the level of legal consciousness of the population, to teach the citizens to respect law, State and society.

\section{References:}

Akimov, O. O. (2014). Psykholohichni aspekty proiaviv koruptsii v derzhavnomu upravlinni [Psychological aspects of manifestations of corruption in public administration]. Public Administration: Theory and Practice, 1, $181-188$. (in Ukrainian)

Beliavskii et al. (1956). Vsemirnaia istoriia. Entsyklopediia [World History. Encyclopedia]. Moskow: State Publishing House of Political Literature. (in Russian)

Blank, M. E., \& Batrakova, T. I. (2016). Vplyv koruptsii na ekonomiku Ukrainy [Impact of corruption on the economy of Ukraine]. Scientific Bulletin of Uzhgorod National University, 7, part 1, 25-28. (in Ukrainian)

Busel, V. T. (2003). Velykyi tlumachnyi slovnyk suchasnoi movy [A great dictionary of modern language]. Kyiv: VTF Perun. (in Ukrainian)

Dzhuzha, O. M. (2010). Ekonomichna bezpeka [Economic security]. Kyiv: Alerta; KNT: Center for Educational Literature. (in Ukrainian)

Hvozdetskyi, V.D. (2012). Koruptsiia - yak sotsialne, psykholohichne i moralne yavyshche [Corruption as a social, psychological and moral phenomenon]. Law, 3, 161-167. (in Ukrainian)

Klimova, S. M., \& Kovalova, T. V. (2012). Orhanizatsiia zapobihannia ta protydii koruptsii v Ukraini [Organization of Prevention and Countering Corruption in Ukraine]. Kharkiv: KharRI NADU "Mahistr". (in Ukrainian)

Kondratiev, Y. (2004). Slovnyk spetsialnykh terminiv pravookhoronnoi diialnosti [Dictionary of special terminology of law enforcement activities]. Kyiv: National Academy of Internal Affairs of Ukraine. (in Ukrainian)

Kovalenko, V. et al. (2011). Mizhnarodna politseiska entsyklopediia [International Police Encyclopedia]. Vol. VII: Administrative and legal support of police activity. Kyiv: Ataka. (in Ukrainian)

Melnik, M. I. (2002). Kryminolohichni ta kryminalno-pravovi problemy protydii koruptsii [Criminological and Criminal-Law Problems of Combating Corruption]. Doctor of Legal Sciences Dissertation. Kyiv. (in Ukrainian)

Official web site of Solomianskyi district state administration (2014). Pravova storinka: koruptsiia [Legal page: Corruption]. Retrieved from: http://www.solor.gov.ua/info/19/7246 (accessed December 30, 2019). (in Ukrainian)

Popov, V. I. (1996). Korruptsiia v Rossii: sostoianie y problemy [Corruption in Russia: the state and problems]. Proceedings of the research and practical conference (Moskow, March 26-27). (in Russian)

Robertson, A. (2006). Misunderstanding Corruption, Anthropology Today, 22(2), 8-9.

Soloviov, V. M. (2011). "Pobutova koruptsiia”: sutnist, geneza ta suchasni tendentsii v Ukraini [Household Corruption: Essence, Genesis, and Modern Trends in Ukraine]. Fighting Organized Crime and Corruption (Theory and Practice), 25-26, 173-182. (in Ukrainian)

Stashys, V. (2001). Problemy borotby z orhanizovanoiu zlochynnistiu i koruptsiieiu v Ukraini [The Problems of Countering Organized Crime and Corruption in Ukraine]. Bulletin of the Academy of Legal Sciences of Ukraine, 2, 163-168. (in Ukrainian)

Transparency International (2009). The Anti-Corruption Plain Language Guide. Germany: Berlin, International Secretariat. 